Maria Murumaa-Mengel, Andra Siibak:

\title{
Teachers as nightmare readers: Estonian high-school teachers' experi- ences and opinions about student-teacher interaction on Facebook
}

\begin{abstract}
:
This study explored Estonian teachers' perceptions and practices about student-teacher interaction on Facebook. Four focus group interviews with high-school teachers $(n=21)$ revealed that educators are used to monitoring their students' posts on Facebook and consider it their role to intervene whenever something inappropriate is posted. Teachers viewed such social media surveillance as a routine and harmless practice which does not violate students' privacy. The participants of our study do not see any need for formal social media policies to regulate student-teacher interaction on social media, as they consider themselves perfectly capable of making ethical choices in this realm.
\end{abstract}

\section{Agenda:}

Introduction 37

Theoretical Background

Teachers and students in social media

Guidelines and policies about social media use in schools

Methodology 38

Results and Discussion 39

Monitoring students' online content creation

Separating public and private.

Teachers' attitude about the need for social media regulations

Conclusion

\section{Authors:}

Maria Murumaa-Mengel:

- Institute of Social Sciences, University of Tartu. Lossi 36, 51003 Tartu, Estonia

- - +372 56267322, $\square$ maria.murumaa@ut.ee

- Relevant publications:

- Murumaa, M. \& Siibak, A. (2012). The Imagined Audience on Facebook: Analysis of Estonian Teen sketches about Typical Facebook Users. First Monday 17(2). URL:http://firstmonday.org/htbin/cgiwrap/bin/ojs/index.php/fm/article/view/3712/3147

- Siibak, A. \& Murumaa-Mengel, M. (2013). Exploring the potential of creative research for the study of imagined audiences: a case-study of Estonian students' sketches on typical Facebook users. In: Patriarche, G., Bilandzic, H., Linaa Jensen, J. \& Jurisic, J. (eds.). Audience Research Methodologies: Between Innovation and Consolidation. London: Routledge. pp. 127-143. 
Dr. Andra Siibak:

- Institute of Social Sciences, University of Tartu. Lossi 36, 51003 Tartu, Estonia

- $\mathbf{\Psi}+372$ 5174146, $\bowtie$ andra.siibak@ut.ee

- Relevant publications:

- Christine W. Trültzsch-Wijnen, Sascha Trültzsch-Wijnen, Siibak, A. (forthcoming 2015). Using and not using social media: what triggers young people's SNS practices? Zeller, F., Ponte, C. and O'Neill, B. (Eds). Revitalising Audience Research. Innovations in European Audience Research. London \& New York: Routledge

- Oolo, E. \& Siibak, A. (2013). Performing for one's imagined audience: main online privacy strategies of Estonian teens. Cyberpsychology, 7(1), http://www.cyberpsychology.eu/view.php?cisloclanku=2013011501\&article $=7$

- Vittadini, N., Siibak, A., Bilandizic, H., \& Carpentier Reifova, I. (2013). Generations and media: social construction of generational identity and differences. In: Carpentier, N., Schrøder, K.C. \& Hallett, L. (eds). Transforming Audiences, Transforming societies. London: Routledge, 65-81.

- Kalmus, V., von Feilitzen C., \& Siibak, A. (2012) Evaluating the effectiveness of teachers' and peer mediation in supporting opportunities and reducing risks online. In: Livingstone, S., Haddon, L. \& Görzig, A. (Eds.). Children, risk and safety online: Research and policy challenges in comparative perspective. Bristol: Polity Press, 245-256. 


\section{Introduction}

At the era of "public surveillance" (Nissenbaum, 2004) and due to the "context collapse" (Marwick \& boyd, 2010) in networked publics, students and teachers have suddenly gained access to each other's information which previously was considered private.

The aim of this article is to investigate Estonian high-school teachers' experiences and opinions about teacherstudent interaction on Facebook. Although there has been a heated debate in the USA about whether it is ethical and legal for teachers to interact with their students on social networking sites (SNS) (Fulmer, 2010; Miller, 2011; Lehrer, 2011), the topic has gained much less attention in European context. For instance, in comparison to many school districts and states in the USA (e.g. Louisiana, Texas, etc.) which have passed policies and regulations designed to limit teacher-student interactions on social media (Lehrer, 2011), similar student-teacher communication bans are rare in the European context (German state bans...2013; Flynn, 2012). Furthermore, academic debate and analysis on the topic so far has either focused on university student-professor relationships on SNS (e.g. Malesky \& Peters, 2012; Karl \& Peluchette, 2011), or on studying the views of pre-service teachers (e.g. Mikulec, 2012; Hart \& Steinbrecher, 2011), whereas the opinions and experiences of practicing high-school teachers are still rarely explored (Asterhan et al., 2013; Williams, 2012).

Our previous research (Murumaa \& Siibak, 2012) has indicated that Estonian students often perceive their teachers on SNS as "nightmare readers" (Marwick and boyd, 2010), i.e members of the audience that the information disclosed on SNS is not originally meant for. So far, there has been no public discussion about teacher-student relationships on SNS in Estonia and to the knowledge of the authors no schools have developed any social media policies or guidelines for the teachers to regulate student-teacher interaction on the Internet. Considering the fact that overall Internet use amongst 11-18 year old Estonians is $99.9 \%$ (Kalmus et al., 2009) and majority of the teens (85\%) have a profile on SNS (Livingstone et al., 2011), we believe additional knowledge is needed on the topic. Furthermore, as teachers are historically seen as mentors and role models for the youth (Miller, 2011), we think it is crucial to learn about teachers' experiences and opinions on an issue which is often depicted as relatively problematic and ethically questionable.

Considering the above and relying on Foulger et al.'s (2009: 18) claims that "studies of inservice teacher reasoning about teacher jurisdiction in student social networking behaviors would help to clarify "expert" perspectives" and "studies of teacher attitudes toward various school-wide policies about social networking use would help illuminate the kinds of guidance that teachers find useful", we set out to explore Estonian high-school teachers' opinions and experiences about monitoring their students' profiles; their opinions about the need to intervene in their students' online content creation practices and their attitudes about the need for school-wide SNS polices.

\section{Theoretical Background}

\section{Teachers and students in social media}

As teachers play a unique role in shaping the minds of our youth educators are usually held to higher standard of professionalism and moral character. In fact, "uprightness of character" (Lumpkin, 2008: 46) is expected of them even during off-duty times (Foulger et al., 2009), the latter of which can nowadays often be spent on social media. As stated by Osman et al (2012) for teachers of today, "online identity is a significant part of their lives and abstinence from these forums is not a realistic option".

Previous studies indicate that there is no consensus among authors whether educators and students should be friends on Facebook or not (Acar, 2013). While many studies suggest that SNS provide an open and supportive environment for teacher-student interaction (Akiti, 2012), others (e.g. Kist, 2008) have drawn attention to negative aspects, that teachers may be afraid of objectionable student comments or blog posts and are therefore deciding against using such platforms. 
Surely, electronic media has thoroughly blurred the boundaries between the public and the private (Meyrowitz, 1985). According to Westin (1968) privacy is an individual's right to decide when, how and how much information about oneself is communicated to the others. However, in the mutual surveillance of social media, or the omnopticon, as Linaa Jensen (2010) has called it, all participants have different understanding of what is correct and incorrect, what is perceived to be normal and abnormal, private and public. As to a large extent, the internet lacks universally applicable laws or even shared norms and values (Albrechtslund, 2008).

The young are often at the forefront of emerging Internet usage practices but at the same time "young people are assumed to be far too naïve to handle themselves in public without careful supervision and control" (Maranto \& Barton, 2010), the same assumption goes for SNS. But what adults regard as risks and reprehensible behavior, the young may see as opportunities (Kalmus \& Ólafsson, 2013) and as an accepted shift in social norms (Shih, 2011).

\section{Guidelines and policies about social media use in schools}

Schools in USA have incorporated many different aspects into their guidelines for social media use, ranging from strict "employees shall not "friend" current students on SNS such as Facebook and MySpace" and "will not respond to student-initiated attempts at conversation" (Dayton Public Schools...2014) to more general suggestions like "each employee has a responsibility to understand the rules of the social media site being utilized" (NYC Department of...2013).

Most policies and guidelines emphasize similar recurring aspects, like separation of personal and professional identities. For example, NYC Department of Education's Social Media Guidelines (2013) separate professional school-based social media use (e.g. teachers establishing blogs or pages for students) and personal use. Social media is mostly seen as a professional workplace and extension of a classroom, where the same rules of conduct apply. For instance, contact with students is preferred to take place in groups and spaces designed for learning, not via personal profiles (teachers "friending" students is often prohibited, or at least frowned upon). The guidelines (e.g. Guidelines for Policy...2010) also emphasize the need to protect students' rights. For example, not only are teachers warned against posting information, visual materials in particular in online environments, but also parental consent is needed before disclosing information about one's students in an online setting. Some schools are also paying attention to students' right for informational privacy (Craig \& Ludloff, 2011), which include "respecting students' personal social media presences" and avoiding "online 'sting' operations" (Larson, 2013).

\section{Methodology}

Four focus group interviews with Estonian teachers $(n=21)$ from different high-schools were carried out in spring 2013 (from March to June) to analyse their perceptions, encounters, and experiences in relation to privacy and publicity in the digital area. By stimulating group dynamics we hoped to identify the opinions our participants shared (Patton, 2002) and create a situation similar to real life interaction.

All of the teachers belonging to our strategic sample had to have a Facebook account and needed to teach in high school. We also aimed to have at least one class teacher ${ }^{120}$ in every focus group, because they tend to have a closer relationship with their students. Our final sample comprised of 3 men and 18 women who taught different subjects in their respective schools and were in between the ages of 23-51. Most of the participants had used SNS also prior to using Facebook.

\footnotetext{
${ }^{120}$ A teacher who is responsible for a class of pupils for several years (e.g. three years in high-school). Class teachers mediate administrative information, organize events and field trips, evaluate students' personal development and communicate with parents and guardians.
} 
An hour to two-hour-long interviews were conducted by two interviewers in schools where the teachers work so as to help participants settle into discussions more rapidly and provide an easily accessible and suitable environment. In the first phase of the focus groups, the participants were asked more general questions about their overall social media usage practices, preferences and the meaning of privacy. Then the discussion moved to the differences in students' and teachers' perceptions about private and public information. In the final phase of the interviews the relationships of teachers and students on Facebook were looked at more closely and the participants discussed the principles of such communication, netiquette, ideals and common practices. In the context of the article at hand we will concentrate on the latter two topics.

As we already had some previous knowledge on the topic (Murumaa \& Siibak, 2012) before starting the study, theoretical and selective coding (Lonkila, 2004) was used for analysing the data gathered. In order to ensure reliability three different researchers analysed the material. After close readings and initial open coding which helped us to structure different codes into more logical systems, we used axial coding so as to focus and work on the codes gathered from one specific category. In other words, step-by-step we were moving to more and more abstract level of analysis.

\section{Results and Discussion}

\section{Monitoring students' online content creation}

The findings of our study suggest that teachers are to a large extent what Marwick and boyd (2010) called "nightmare readers"- people who are not the imagined audience of the students' posts but nevertheless keep an eye on their online content creation. Hence, in contrast to the young who believe that social media and SNS in particular, is "'their" space, visible to the peer group more than to adult surveillance" (Livingstone, 2008: 396), various adults e.g. teachers are actually monitoring the practices of the young in online settings.

F5: holy heavens, they can't imagine that all of their questions and answers are visible there [on ask.fm]. I haven't told them that I see that, cunningly.

In comparison to a district in Glendale, California, where a tech firm was hired to monitor students' posts (Martinez, 2013), our focus groups revealed that teachers themselves had taken up the task. Furthermore, as high standards were part of the participating teachers' self-image many of them talked about occasions when they had taken up a role of a controller who is ready to take action in case of noticing something inappropriate.

F7: And I have warned them, when I know that there is a birthday coming up or something, then I say that I do not want to see any photos with alcohol bottles on Facebook afterwards /---/ and sometimes when they are absent a lot, I sometimes go to check and they have pictures of parties up and... (general laughter)

In general, the teachers in our sample had noticed four main content related problems when monitoring students' Facebook posts. First of all, the teachers believed and had noticed that young people often tend to post too revealing images on Facebook i.e. they post photos that reveal something about the student's romantic relationship or literally reveal their bodies. Furthermore, teachers also believed the students to over-expose their emotions e.g. by proclaiming their love to someone several times a day on social media; and to make posts which could be considered either harmful i.e. malicious gossip and cyberbullying or illegal e.g. exposing the use of drugs or alcohol. In contrast to the student posts which could be considered bullying or which threaten public safety (e.g. school shootings) and are argued not to be "detected or solved without adult presence within [italics in the original] the medium" (Asterhan et al., 2013), teachers in our sample also talked about the need to intervene in situations like the one below, where a moral dilemma and controversial paths of actions exist. 
F18: I have seen a herd of half-naked girls in the shower, students shared their pictures. Really, we made a big deal about it and they didn't see what the problem was. That it was their personal affair.

The abovementioned example illustrates nicely that "our thinking about privacy in technological interactions is complicated" (Foulger et al., 2009) and that privacy means different things to different people. In comparison to a teacher who does not question the school's need to intervene, students themselves considered the situation to be a private matter and any outside intervention thus unnecessary. Nevertheless, our findings reveal that similar to the participants in Williams' (2012) study, the teachers that we interviewed also felt a heightened need to teach digital etiquette to the students. Their educational practices however, might be questionable at times.

For instance, although the teachers in our sample expressed the understanding that it is not suitable to talk about real problems they have witnessed on Facebook publicly in classroom settings, an extract from below suggests that some of them had still made use of specific cases they had witnessed on Facebook so as to trigger in-class discussions.

F4: polite and nice girl in my last class, I don't remember which teacher I googled and then her blog came up. And I talked about it in class, of course without naming names and the girl told me afterwards that she wishes she had known it, she will never do that again.

As the example below demonstrates how the focus groups also revealed that teachers have used specific cases to give their students a lesson about privacy, everlasting memory of the Internet, and other possible problems; their strategies were sometimes questionable.

F5: a girl was sleeping in class, you know? Someone took a photo, put it up. On Facebook. I downloaded the photo and then wrote that I think you should take it down, it's not nice. They apologized and took it down and then I said that I can put it up myself now.

It appears that although the teachers have the best interest of their students at heart, they tend not to think their actions through from the teens' perspective. By publicly humiliating and embarrassing students, teachers' educational purposes may not turn out to be as effective as they have hoped for.

\section{Separating public and private}

In light of recent surveillance society discussions, the teachers in our sample sometimes noted with a smirk that "big brother" is watching us all anyway, so they considered the problematization of privacy to be somewhat a pseudo-topic. In fact, many Estonian teachers interviewed for this study said that privacy issues are "in fashion" and there is almost an over the top moral panic around this subject, especially when talking about students' privacy:

F8: I feel that our generation doesn't demand privacy so horribly, I feel like it's a trend topic, not a deeper thought and maybe the young are going along with fashionable trends and thus are after this privacy, too.

As the example above demonstrates opinions about privacy and publicity were often explained by generational differences in values and norms. In fact, participating teachers emphasized constantly that they view Facebook and other social media platforms to be public, and compared communication on social networking sites to writing an open letter or to giving a speech in a public park and compared private space to the contents of a handbag or a diary. The latter is probably also a reason why participating teachers seemed to have a hard time adjusting to the fact that young people's Facebook posts may often touch upon topics of emotions e.g. romantic emotions, grief, etc. that have mainly seen as private by previous generations. 
F7: when $x$ died then I looked at x's Facebook page and there were all these comments...I wouldn't have dared to write there /---/ or when that girl got killed there. They, how will I put it, share this information very naturally, like it is a normal thing to comment and offer condolences like that.

Our findings indicate that teachers in our sample tended to characterize themselves as members of previous generations who still remember a world where there was luxury of controlling the spread of information about oneself (Abril, 2007) and contrasted their own views to the ones of the present day young people. The young, however, were believed to have accepted a world of collapsed contexts (Marwick \& boyd, 2010) where information flows freely. Anecdotally, in one case, a participating teacher expressed an opinion that schools should hire hackers, so that "teachers can access these communities the students have". This is a serious discord in opinions, as most students "value privacy, seek privacy from both strangers and known others online, and use a variety of strategies to protect their privacy online" (Davis \& James, 2012).

\section{Teachers' attitude about the need for social media regulations}

In comparison to the findings of Williams (2012) whose study participants claimed that there is a need for revised polices about the matter, all the participants in our study stated that their schools do not have specific guidelines for student-teacher interaction on social media (only general rules of conduct), nor are such guidelines necessary. In fact, teachers in our sample were certain that they have the knowledge and skills to handle problems that might rise and valued (creative) freedom of not being the subject of strict rules. Such a strong and negative stance towards rules and regulations that was shared by our participants is generally different from the attitude in the USA where some school boards have gone even so far as to prohibit parents who are teachers from "friending" their own children who happen to be students (Akiti, 2012). Teachers in our sample believed that instead of strict rules and guidelines one simply needs to be a "thinking rational person" whose previous encounters in social media should offer enough knowledge and skills even so as to interact with students in an adequate manner. In fact, the teachers in our sample believed all teachers to be intelligent enough not to need any formal rules of the kind.

F14: everybody here are intelligent people and we can communicate, we do not need any training in that. /---/ And there are so many norms in life, here we have intelligent teachers working in school and I think that we do not need official regulations on how they [teachers and students] communicate on Facebook.

In addition to the feeling of professional pride that was expressed through abovementioned remarks, such comments reveal that the participants in our study internalized the image of a teacher as a moral compass of the society. In other words, the descriptions of our interviewees depicted a teacher to be almost as an ideal citizen who makes no mistakes and is a role model to others. Such a stance indicates that our participants either looked past the fact that there have been cases where teachers have posted inappropriate comments and images or had indecent interactions with their students online (e.g. Akiti, 2012), or they were simply unaware of such cases. Considering that there has not been any news articles about inappropriate studentteacher interactions in Estonian media, it could very well be that our participants might have not even heard about international cases of the kind (e.g. Heussner \& Fahmy, 2010).

\section{Conclusion}

Society seems sometimes frightened of teachers having genuine relationships with students, including sharing personal aspects of their lives (Kist, 2008) as teachers are expected to behave like Educators twenty-four hours a day, seven days a week. In some parts of the world, teachers have fought for the right to use social media and evoke their right to free speech (Akiti, 2012) because educators have lives outside of school. In addition, teachers can present themselves through Facebook as individuals who function outside of the classroom in social situations and so have positive influence on students' motivation and participation (Mazer et al., 2009). 
At the same time, researched teachers' experiences and opinions about teacher-student interaction on Facebook suggest that educators often live up to the students' perception of them, the "nightmare readers" (Marwick and boyd, 2010; Murumaa \& Siibak, 2012), lurking and monitoring pupils on SNS or even actively intervening in students' online content creation. In many occasions the participants of this study expressed the need to educate their students about possible risks associated with social media, taking on the expected role of teachers as mentors (Miller, 2011; Lumpkin, 2008). Although teachers' aim was clearly to prevent harm and so to say to "save the students from themselves", both their opinions and experiences revealed that they rarely had any ethical or moral dilemmas about their practices.

This raises serious questions about the fundamental informational privacy rights (Craig \& Ludloff, 2011) of students. Mutual online surveillance seems to be the new norm but at the same time, people have to learn how to look away at certain moments and to respect privacy boundaries set by other people, even if they differ from one's own. Too often, teachers interpret online privacy rather black-and-white, disregarding the subtle nuances of contemporary online privacy.

Furthermore, according to the teachers in our sample students' privacy is more like a "pseudo-topic" than anything teachers should really be concerned about. Furthermore, they believed privacy to be a topic which every teacher already has knowledge about and thus they did not see any need for policies or guidelines to regulate their interactions with students in social media. However, as numerous problematic cases from different countries demonstrate, still more has to be done so as to increase teachers' awareness about informational privacy and online ethics.

\section{Acknowledgements}

The authors are grateful to the Estonian Research Council for the support of the research project PUT44. We would also like to sincerely thank Sandra Räim and Mehis Tuisk for conducting the focus group interviews.

\section{References}

Abril, S. P. (2007). A (My)Space of One's Own: On Privacy and Online Social Networks. Northwestern Journal of Technology and Intellectual Property, 6. Available from: http://ssrn.com/abstract=1392285

Acar, A. (2013). Attitudes toward Blended Learning and Social Media Use for Academic Purposes: An Exploratory Study. Journal of E-Learning and Knowledge Society, 9(3). Available from: http://www.je-lks.org/ojs/index.php/Je-LKS_EN/article/view/809

Albrechtslund, A. (2008). Online Social Networking as Participatory Surveillance. First Monday, 13(3). Available from: http://firstmonday.org/htbin/cqiwrap/bin/ojs/index.php/fm/article/viewArticle/2142/1949

Akiti, L. (2012). Facebook off Limits? Protecting Teachers' Private Speech on Social Networking Sites. Valparaiso University Law Review, 47(1): 119-167. Available from: http://scholar. valpo.edu/vulr/vol47/iss1/4

Asterhan, C. S. C., Rosenberg, H., Schwarz, B. B., \& Solomon, L. (2013). Secondary School Teacher - Student Communication in Facebook: Potentials and Pitfalls. In: Y. Eshet-Alkalai, A. Caspi, S. Eden, N. Geri, Y. Kalman, \& Y. Yair (Eds), Proceedings of the Chais conference on instructional technologies research 2013: Learning in the technological era. Raanana: The Open University of Israel.

Craig, T. \& Ludloff, M. E. (2011). Privacy and Big Data: The Players, Regulators, and Stakeholders. Sebastopol: O'Reilly Media.

Davis, K. \& James, C. (2013). Tweens' Conceptions of Privacy Online: Implications for Educators. Learning, Media and Technology, 38(1): 4-25.

Flynn, S. (2012, June 4). Facebook "Friends" Rules Set for Teachers. The Irish Times. Available from: http://www.highbeam.com/doc/1P2-31488995.html

Foulger, T. S., Ewbank, A. D., Kay, A., Popp, S. O., \& Carter, H. L. (2009). Moral Spaces in MySpace. Journal of Research on Technology in Education, 42(1): 1-28. 
Fulmer, E. H. (2010). Privacy Expectations and Protections for Teachers in the Digital Age. Duke Law and Technology Review, 14: 1-30.

Hart, J. E., \& Steinbrecher, T. (2011). OMG! Exploring and Learning from Teachers' Personal and Professional Uses of Facebook. Action in Teacher Education, 33(4), 320-328.

Heussner, K. M., \& Fahmy, D. (2010, August 19). "Germ Bags": Teacher Loses Job Over FB Posts. ABC News. Available from: http://abcnews.go.com/Technology/facebook-firing-teacher-loses-job-commenting-students-parents/story?id=11437248

Hew, K. F. (2011). Students' and Teachers' Use of Facebook. Computers in Human Behavior, 27(2): 662-676.

Kalmus, V., Ólafsson, K. (2013). 'Editorial: A Child-Centred Perspective on Risks and Opportunities in Cyberspace'. Cyberpsychology: Journal of Psychosocial Research on Cyberspace 7(1). Available from: http://Www.cyberpsychology.eu/view.php?cisloclanku=2013022201\&article=1

Kalmus, V., Pruulmann-Vengerfeldt, P., Runnel, P., Siibak, A. (2009). Mapping the Terrain of "Generation C": Places and Practices of Online Content Creation among Estonian Teenagers. Journal of Computer-Mediated Communication, 14(4): 1257-1282.

Karl, K. A. \& Peluchette, J. V. (2011). "Friending" Professors, Parents and Bosses: A Facebook Connection Conundrum. Journal of Education for Business, 86(4): 214-222.

Kist, W. (2008). "I Gave Up My Space for Lent": New Teachers and Social Networking Sites. Journal of Adolescent \& Adult Literacy, 52(3): 245-247.

Larson, E. (2013). Should Schools Implement Social Media Policies? Mashable.com. Available from: http://mashable.com/2013/07/01/school-social-media-policy/

Lehrer, A. (2011). Keeping the Poking to Yourself Mrs. Robinson: The Missouri Facebook Statute and its Implications for Teacher Free Speech under the First Amendment. Seton Hall Law e-Repository, Available from: http://scholarship.shu.edu/cgi/viewcontent.cgi?article=1001\&context=student scholarship

Linaa Jensen, J. (2010). The Internet Omnopticon - Mutual Surveillance in Social Media. Paper presented at Internet research 11.0: Sustainability, Participation, Action (Gothenburg, Sweden).

Livingstone, S. \& K. Ólafsson, \& E. Staksrud (2011). Social Networking, Age and Privacy. LSE, London: EU Kids Online.

Livingstone, S. (2008). Taking Risky Opportunities in Youthful Content Creation: Teenagers' Use of Social Networking Sites for Intimacy, Privacy and Self-Expression. New media \& society, 10(3). Available from: http://eprints./se.ac.uk/27072/1/Taking risky opportunities in youthful content creation \%28LSERO\%29.pdf

Lonkila, M. (2004). Grounded Theory as an Emerging Paradigm for Computer-assisted Qualitative Data Analysis. In: U. Kelle, G. Prein, K. Bird (Eds.), Computer-Aided Qualitative Data Analysis. Theory, Method and Practice. London: Sage Publication, pp 41-51.

Lumpkin, A. (2008). Teachers as Role Models Teaching Character and Moral Virtues. JOPERD, 79(2): 45-49.

Malesky, L. A. \& Peters, C. (2012). Defining Appropriate Professional Behavior for Faculty and University Students on Social Networking Websites. Higher Education, 63(1): 135-151.

Maranto, G. \& Barton, M. (2010). Paradox and Promise: MySpace, Facebook, and the Sociopolitics of Social Networking in the Writing. Computers and Composition 27(1): 36-47

Martinez, M. (2013, September 18). California School District Hires Firm to Monitor Students' Social Media. Available from: http://edition.cnn.com/2013/09/14/us/california-schools-monitor-social-media/index.htm/

Marwick, A. E. \& boyd, d. (2010). I Tweet Honestly, I Tweet Passionately: Twitter Users, Context Collapse, and the Imagined Audience. New Media \& Society, 13(1): 114-133.

Mazer, J., Murphy, R., \& Simonds, C. (2009). Effects of Computer Mediated Teacher Self-Disclosure on Student Motivation, Affective Learning and, Classroom Climate. Communication Education, 56(1): 1-17.

Meyrowitz, J. (1985). No Sense Of Place: The Impact Of Electronic Media On Social Behavior. US: Oxford University Press etc.

Mikulec, E. A. (2012). Professional Faces: Pre-Service Secondary Teachers' Awareness of Issues of Self-Disclosure on Social-Networking Sites. Current Issues in Education, 15(3), Available from: http://cie.asu.edu/ojs/index.php/cieatasu/article/view/938

Miller, R. A. (2011). Teacher Facebook Speech: Protected or Not?. Brigham Young University Education \& Law Journal, 2: 637-665 
Murumaa, M. \& Siibak, A. (2012). The Imagined Audience on Facebook: Analysis of Estonian Teen sketches about Typical Facebook Users. First Monday, 17(2). Available from:

http://firstmonday.org/htbin/cgiwrap/bin/ojs/index.php/fm/article/view/3712/3147

Nissenbaum, H. (2004). Privacy as Contextual Integrity. Washington Law Review, 79(1): 119-157.

Osman, A., Wardle, A., \& Caesar, R. (2012). Online Professionalism and Facebook - Falling Through the Generation Gap. Medical Teacher, 34: 549-556.

Patton, M. Q. (2002). Qualitative Research and Evaluation Methods. Thousand Oaks, CA: Sage Publications.

Shih, C. (2011). The Facebook Era. Tapping Online Social Networks to Market, Sell, and Innovate. New Jersey: Prentice Hall.

Westin, A. (1968). Privacy and Freedom. New York: Atheneum.

Williams, W. R. (2012). Digital Immigrant Teacher Perceptions of Social Media as it Influences the Affective and Cognitive Development of Students: a Phenomenologial Study. Dissertation, Liberty University, Lynchburg, VA. Available from: http://digitalcommons.liberty.edu/cgi/viewcontent.cgi?article=1613\&context=doctoral

Dayton Public Schools Policy Manual (updated March 2014). Available from: http://www.dps.k12.oh.us/aboutus/board-policy-manual. html

German state bans student-teacher contact on Facebook. (2013, October 22). Capital News. Available from: http://www.capitalfm.co.ke/news/2013/10/german-state-bans-student-teacher-contact-on-facebook/

Guidelines for Policy \#470: Social Media Networks. (2010). Minnetonka Public Schools. Available from: http://www.minnetonka.k12.mn.us/policies/470.pdf

NYC Department of Education Social Media Guidelines. (2013). NYC Department of Education Home Page. Available from: http://schools.nyc.gov/NR/rdon/yres/BCF47CED-604B-4FDD-B752DC2D81504478/0/SMG FINAL 20130415.pdf 